The Saxophone 
Also available in the series

The Flute

Ardal Powell

Timpani and Percussion

Jeremy Montagu

The Oboe

Geoffrey Burgess and Bruce Haynes

The Trombone

Trevor Herbert

The Clarinet

Eric Hoeprich

The Trumpet

John Wallace and Alexander McGrattan

The Bassoon

James B. Kopp 
THE YALE MUSICAL INSTRUMENT SERIES

\section{The Saxophone}

Stephen Cottrell

Yale University Press

New Haven and London 
Copyright (C) 2012 by Stephen Cottrell

All rights reserved. This book may not be reproduced in whole or in part, in any form (beyond that copying permitted by Sections 107 and 108 of the U.S, Copyright Law and except by reviewers for the public press), without written permission from the publishers.

For information about this and other Yale University Press publications please contact: U.S. Office: sales.press@yale.edu yalebooks.com

Europe Office: sales@yaleup.co.uk_www.yalebooks.co.uk

Set in Columbus MT by IDSUK (DataConnection) Ltd

Printed in Great Britain by TJ International Ltd, Padstow, Cornwall

Library of Congress Control Number

Cottrell, Stephen, I962-

The saxophone / Stephen Cottrell.

p. $\mathrm{cm}$.

ISBN 978-0-300-I004I-9 (cl: alk. paper)

I. Saxophone-History. 2. Sax, Adolphe, I8I4-I894. I. Title.

ML975.C67 2013

$788.7-\mathrm{dc} 23$

2012028346

A catalogue record for this book is available from the British Library.

IO $9 \begin{array}{lllllllll} & 8 & 7 & 6 & 5 & 4 & 3 & 2 & \text { I }\end{array}$ 
For my parents, Dennis and Eunice Cottrell 
